\title{
RISK: ECONOMIC CONTENTS, FACTORS AND METHODS OF MANAGEMENT
}

\author{
Lilia MARTYNOVA ${ }^{1}$ \\ V. Dahl East Ukrainian National University, Ukraine
}

\begin{abstract}
The purpose of article is determination of economic content of risks, their classification and methods of management, research of influence of major factors of risk on results of economic activity of the agro-industrial complex enterprises on possible degree of their controllability, and also justification of the choice of the most optimum methods of management of economic risks at the enterprises of agrarian sector of economy. Methodology. Data for research have been taken from scientific publications and legislative base. Methods of general scientific knowledge, and also the structural analysis and content analysis are used. Results. On the basis of synthesis of approaches to definition of category of «economic risk» by the author own definition of this category is offered, the scheme of distribution of risk factors of economic activity of the enterprises of agro-industrial complex depending on main types of business processes on possible degree of their controllability is offered, and also the author offers the direction of classification of methods of management of risks from positions of their distribution or transfer, besides practical aspects of the choice of methods of economic risks management at the enterprises of agrarian sector of economy are considered. Practical implication. Streamlining of subject domain of risk management of economic activity and the offered structurization of risk factors create prerequisites for increase of system effectiveness of management at the enterprise due to reduction of negative influence of risk factors, increase of level of validity of administrative decisions in the short-term and long-term periods. Value/originality. On the basis of the conducted research it is proved that a perspective form of diversification of risks in the sphere of agro-industrial complex is creation of regional clusters.
\end{abstract}

Key words: risk of economical activity, risk factors, classification of risk, business process, management of risks, methods of management risks, classification of methods of management risks, diversification, hedging, futures, option, limiting, insurance, cluster.

JEL Classification: 013, Q01, Q19

\section{Introduction}

In the conditions of instability of the surrounding economic environment and the general crisis state of economy, influence of negative risk factors on activity of the enterprises of agro-industrial complex increases. Sources of emergence of risks in this sphere have the features. It is connected with the fact that on results of economic activity of the enterprises of agro-industrial complex together with factors which cause an economic situation in the country considerable impact is exerted by a climatic factor.

In such conditions requirements to an enterprise management system raise, one of the most important links of which there is a subsystem of risk management of economic activity. The market environment which is characterized by variability and uncertainty promotes objective emergence of risky situations in activity of the enterprises which, in turn, induce the management of the enterprise to consider, estimate in due time risks and to make adaptive decisions concerning reduction of their negative influence on results of economic activity. Therefore the tools of risk management at the enterprises of agro-industrial complex have to consider features of this field of economy.

In this regard, special relevance is acquired by scientific researches on questions of economic maintenance of risks, negative influence of major factors of risk on results of economic activity of the enterprises of agro-industrial complex and the directions of its reduction, and also the choice of effective methods of management of economic risks at the enterprises of agro-industrial complex.

\section{Economic content of risk}

Emergence of risk as economic category is identified with emergence in the society of the commodity-money relations when the risk was considered as loss of property owing to overseas travel, attacks of robbers and other force majeure circumstances.

\footnotetext{
Corresponding author:

${ }^{1}$ Department of Economic Law, V. Dahl East Ukrainian National University.

E-mail: mar-sofi@rambler.ru
} 
It is considered that for the first time scientific determination of economic content of risk has been made by the mathematician Yogan Tetens (XVIII century). His scientific researches have found practical application in life insurance though bases of scientific researches on questions of maintenance of risks and their classification have been put in works of scientists D. Graunt, Ja. Witt, E. Galley in the XVII century.

With further development of scientific and technical progress the risk has ceased to be identified only with loss of means for existence. From the insurance sphere this concept has gradually passed and has captured all spheres of life of society, having extended also to the economic theory.
In the period of the Soviet Union attention to a risk problem in researches of economists it was limited as the planned centralized economy provided compensation of losses which arose in her separate branches, at the expense of other branches which number, for example, the branch on production and export of oil and gas treated.

The modern understanding of economic content of risk is connected with consideration of risk not only as the loss received as a result of the made administrative decision but also as a deviation from the planned result.

The analysis of sources of scientific economic literature has allowed allocating three main directions of scientific researches in the sphere of problems of management of

Table 1

Characteristic of interpretations of economic essence of the category «risk»

\begin{tabular}{|c|c|c|c|}
\hline № & $\begin{array}{l}\text { Direction of the scientific } \\
\text { researches }\end{array}$ & Author & Definition of category of risk \\
\hline \multirow{4}{*}{1} & \multirow{4}{*}{$\begin{array}{l}\text { The direction of scientific } \\
\text { researches which covers } \\
\text { problems of the theory, an } \\
\text { assessment and risk analysis } \\
\text { from a probability theory } \\
\text { position. }\end{array}$} & I.T. Balabanov & $\begin{array}{l}\text { In the general understanding defines risk as «probable danger of losses» } \\
\text { (Balabanov, } 1996 \text { p.13) }\end{array}$ \\
\hline & & $\begin{array}{l}\text { P.G Grabova, } \\
\text { S.Ya. Petrov, } \\
\text { K.G. Romanov }\end{array}$ & $\begin{array}{l}\text { «Probability of loss by the enterprise of part of the resources, short- } \\
\text { reception of the income or emergence of additional expenses as a result of } \\
\text { implementation of a certain production and financial activity» (Donets } \\
\text { and other, 2012, p. 91) }\end{array}$ \\
\hline & & N.V. Khokhlov & $\begin{array}{l}\text { «The event or group of similar casual events which cause a loss to } \\
\text { object which owns this risk». That is risk as a separate event according } \\
\text { to the above definition is inherent two properties: probability and loss } \\
\text { (Khokhlov, 2001, p. 11) }\end{array}$ \\
\hline & & A.V. Skripnik & $\begin{array}{l}\text { «The probability of emergence of damage or short-reception have arrived } \\
\text { in comparison with the predicted (expected) option» or «damage size } \\
\text { on the set significance value (with the set probability)» (Skripnik \& } \\
\text { Shevchuk, 2011, pp. 101-108). The author develops methodology of } \\
\text { an assessment of risk of decision-making at the level of separately taken } \\
\text { agrarian enterprise for data of supervision of accounting reports }\end{array}$ \\
\hline \multirow[b]{3}{*}{2} & \multirow{3}{*}{$\begin{array}{l}\text { The direction of scientific } \\
\text { researches which considers } \\
\text { theoretical and practical } \\
\text { problems of application of } \\
\text { economic-mathematical } \\
\text { methods of the analysis } \\
\text { for the purpose of } \\
\text { identification of the actual } \\
\text { deviations from the planned } \\
\text { results }\end{array}$} & S.M. Illyashenko & $\begin{array}{l}\text { «An opportunity or threat of a results deviation of concrete decisions or } \\
\text { actions from expected» (Illyashenko, 2004, p.10) }\end{array}$ \\
\hline & & $\begin{array}{l}\text { V.K. Zbarsky, } \\
\text { A.I. Lipovyak- } \\
\text { Melkozyorova }\end{array}$ & $\begin{array}{l}\text { «Possible deviation from the purposes which are set before themselves } \\
\text { by subjects of economic activity» (Zbarsky \& Lipovyak-Melkozyorova, } \\
\text { 2011, p. 62) }\end{array}$ \\
\hline & & $\begin{array}{l}\text { V.V. Vitlinsky, } \\
\text { L.L. Makhanets }\end{array}$ & $\begin{array}{l}\text { «Economic category which displays characteristics of perception } \\
\text { the interested subjects of the economic relations in the conditions of } \\
\text { objectively available uncertainty and situations of the conflict which are } \\
\text { inherent in processes of establishment of the purposes, managements, } \\
\text { decision-making, estimations which are burdened by possible threats and } \\
\text { unused opportunities» (Donets and other, 2012, p. 91) }\end{array}$ \\
\hline \multirow[t]{3}{*}{3} & \multirow{3}{*}{$\begin{array}{l}\text { The third direction - } \\
\text { considers the separate } \\
\text { theoretical directions of } \\
\text { research of risks and offers } \\
\text { application of techniques } \\
\text { of high-quality and } \\
\text { quantitative measurement } \\
\text { of risk factors. }\end{array}$} & V.V. Chepurko & $\begin{array}{l}\text { The author has proved the generalized definition of category of economic } \\
\text { risk as investigated at inexhaustible uncertainty of the relations between } \\
\text { reality of economic system and opportunities of its transformation } \\
\text { in some future reality identified by the subject which can arise from } \\
\text { interactions of causes and effects, casual and necessary, internal and } \\
\text { external conditions (Chepurko, 2000). In the scientific works he develops } \\
\text { tools of quantitative identification, an assessment and hedging of } \\
\text { economic risks of the agro-industrial enterprises. }\end{array}$ \\
\hline & & O.O. Alshanova & $\begin{array}{l}\text { The author investigates economic risks as objects of insurance and } \\
\text { fruitfully develops risk management methodology by insurance of the } \\
\text { grown-up crops (Alshanova, 2010, pp. 86-91) }\end{array}$ \\
\hline & & E.M. Krylatykh & $\begin{array}{l}\text { The author offers the concept of multifunctionality of research of the } \\
\text { nature of economic risk as one of major factors of overcoming of an } \\
\text { economic crisis and its consequences in agro-industrial sector of economy } \\
\text { of Ukraine (Krylatykh, 2010, pp. 162-165) }\end{array}$ \\
\hline
\end{tabular}




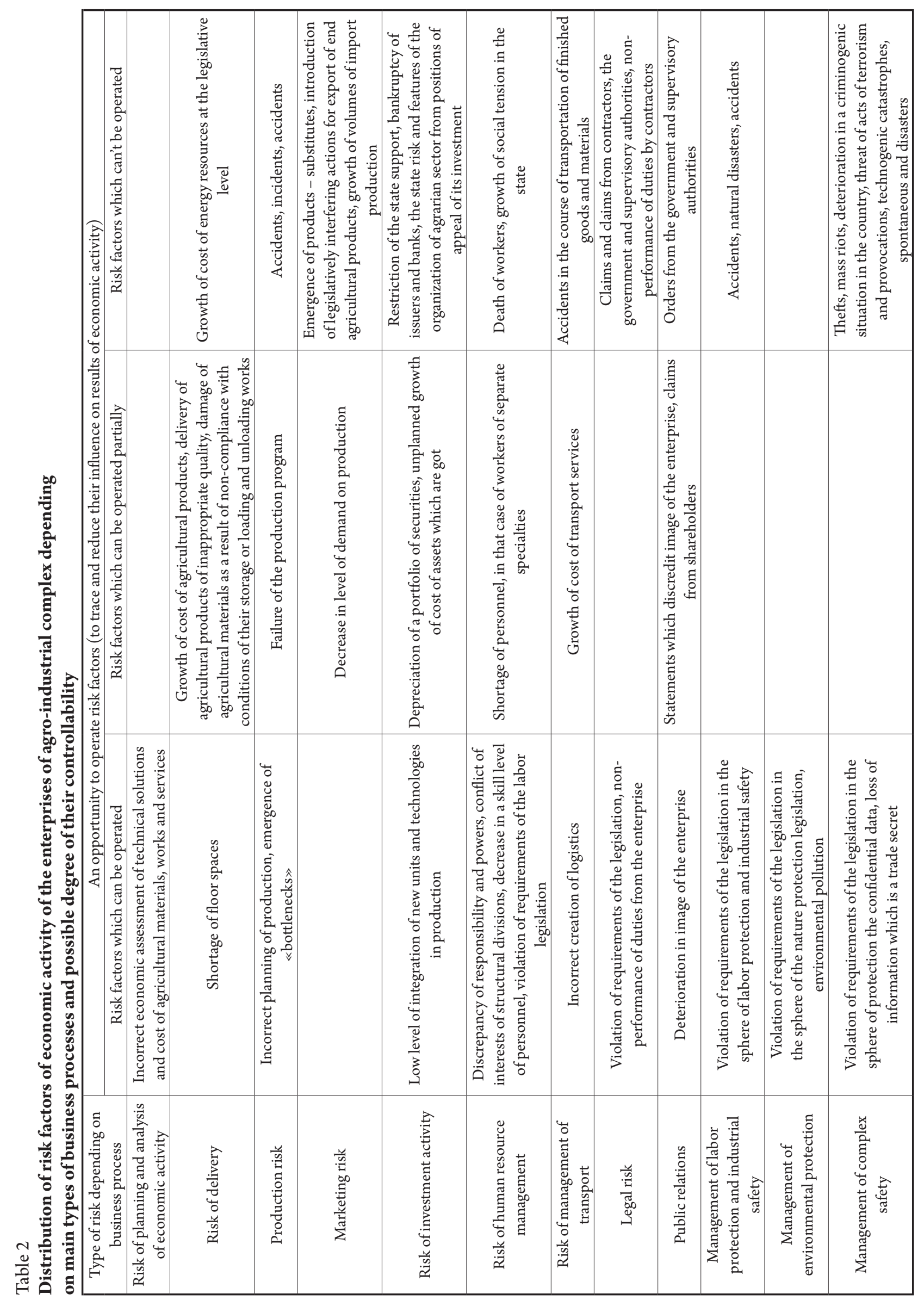


economic risks of the enterprises. The specified directions, their certain representatives and definitions of the category «risk $\gg$ are provided in table 1 .

Systematizing a wide variety of scientific thoughts of the Ukrainian and foreign scientists, it is possible to allocate keywords which characterize the content of the category «economic risk», namely: loss, danger, failure, damage; probability of emergence in economic activity of subjects of losses, dangers, failures, damage; need of the choice and adoption of a certain economic decision.

From here, in our opinion, it is possible to allocate such basic elements of economic content of category of economic risk as:

- probability of emergence of unplanned losses of resources as a result of decision-making;

- a deviation of financial and economic results of activity from planned;

- existence of alternatives of adoption of administrative decisions concerning reduction of negative influence of risk factors.

On the basis of synthesis of approaches to definition of category of «economic risk» by the author her following definition is offered: the economic risk is a difficult objective and subjective category which is characterized by a situation of probability of any loss of resources and/or a deviation of financial and economic results of activity from the available alternatives planned in the conditions of adoption of the administrative decision from the available alternatives.

\section{Classification of risk factors}

The separate attention is deserved by research of a problem of structurization of economic risks. Despite wide-ranging studies in the sphere of a risk management, in economic literature absent the uniform coordinated structurization of economic risks at the enterprises of agro-industrial complex that is connected with the problem field of formation of risks and various levels of their controllability. It is connected with the fact that, the risk is the difficult multidimensional phenomenon which quite difficult is exposed to structurization, in the theory and practice approaches to his classification vary according to the directions and the purpose of researches. The insufficient readiness of a perspective of management of economic risks in the sphere of agro-industrial complex is connected also with system ignoring of risk factors in the current legislation of Ukraine and quite limited application in practical economic and administrative activities of the enterprises both in the sphere of agrarian sector, and in other branches of economy.

It is possible to allocate two main approaches to classification of risks of economic activity: the first approach is connected with development of universal classifications of risks which can be applied in any sphere of economy; the second is connected with development of classifications which are applied in concrete branch of economy, a type of business activity or at the concrete enterprise.

On the basis of systematization of the most known classifications of risks and their design on economic activity of the enterprises of agro-industrial complex by the author distribution of risk factors of economic activity of the enterprise depending on main types of business processes and possible degree of their controllability (tab. 2) is carried out.

It should be noted that risks understand a possibility of tracking as controllability degree of management of the

Table 3

The generalized classification of methods of management of economic risks at the enterprises of agro-industrial complex

(Donets and other, 2012, pp. 193-197; Kachalov, 2002, p. 91; Vasin \& Shutov, 2010, pp. 88-110; Zakharchenko \& Osipov, 2010, pp. 153-165)

\begin{tabular}{|c|c|c|c|}
\hline № & $\begin{array}{c}\text { Classification } \\
\text { directions }\end{array}$ & Methods & Contents \\
\hline \multirow{3}{*}{1} & \multirow{3}{*}{$\begin{array}{l}\text { Ways of } \\
\text { influence on risk }\end{array}$} & Decrease & $\begin{array}{l}\text { Risk exception, decrease in probability of emergence of risk, decrease in } \\
\text { opportunities of a loss }\end{array}$ \\
\hline & & Preservation & Without financing, self-financing, attraction of external sources (grants, loan) \\
\hline & & Transfer & Insurance, receiving financial guarantees, risk transfer \\
\hline \multirow{5}{*}{2} & \multirow{5}{*}{$\begin{array}{c}\text { Methods of } \\
\text { decrease in risk }\end{array}$} & Deviation from risk & $\begin{array}{l}\text { Refusal of implementation of economic operations, of the bank credits, of any } \\
\text { investment policy, of import raw materials supply, etc. in case risk excessively } \\
\text { big and burdening for the enterprise }\end{array}$ \\
\hline & & Acceptance of risk & Acceptance of all risk or its part on responsibility of the enterprise \\
\hline & & Prevention of risk & $\begin{array}{l}\text { Implementation by the enterprise of certain measures and actions which } \\
\text { are directed to prevention of risky situations due to obtaining additional } \\
\text { information, increase of validity of administrative decisions, etc. }\end{array}$ \\
\hline & & $\begin{array}{l}\text { Decrease in risk by economic } \\
\text { methods: }\end{array}$ & \\
\hline & & $\begin{array}{l}\text { - Creation of special reserve } \\
\text { fund or self-insurance }\end{array}$ & $\begin{array}{l}\text { It is created due to assignments from profit of the enterprise on a case of } \\
\text { emergence of unforeseen risky situations or damage for the purpose of ensuring } \\
\text { neutralization of their negative financial consequences in development of the } \\
\text { enterprise, and also in expeditious overcoming of temporary difficulties of } \\
\text { financial and economic activity }\end{array}$ \\
\hline
\end{tabular}




\begin{tabular}{|c|c|c|c|}
\hline \multirow{4}{*}{2} & \multirow{4}{*}{$\begin{array}{l}\text { Methods of } \\
\text { decrease in risk }\end{array}$} & $\begin{array}{l}\text { - Creation of an insurance stock } \\
\text { of goods or means }\end{array}$ & $\begin{array}{l}\text { It is created according to the purpose of compensation of fluctuations of } \\
\text { demand for goods for a possibility of normal functioning in the conditions of } \\
\text { non-performance of schedules of supply and excessive demand for goods: or for } \\
\text { the purpose of compensation of fluctuations of receipts and use of enterprise } \\
\text { assets. }\end{array}$ \\
\hline & & $\begin{array}{l}\text { - Development and } \\
\text { introductions of system of } \\
\text { penalties }\end{array}$ & $\begin{array}{l}\text { It is used only by those types of risk which probability of emergence depends on } \\
\text { contractors of the enterprise }\end{array}$ \\
\hline & & - Insurance & $\begin{array}{l}\text { Insurance companies provide protection against risks by attraction of financial } \\
\text { resources of insurers and their use for compensation suffered by these insurers } \\
\text { of damage }\end{array}$ \\
\hline & & - Hedging & $\begin{array}{l}\text { Activity of the enterprise for decrease in price and inflationary risks by signing } \\
\text { of future agreements - agreements on delivery (purchase) to the term of a } \\
\text { certain quantity of goods determined in the future at the existing price }\end{array}$ \\
\hline \multirow{3}{*}{3} & \multirow{3}{*}{$\begin{array}{l}\text { Forms of } \\
\text { prevention of } \\
\text { risks }\end{array}$} & Avoidance of risk & $\begin{array}{l}\text { Development of actions which entirely exclude a concrete type of enterprise } \\
\text { risk due to refusal of implementation of economic operations when risk level } \\
\text { excessively big and doesn't answer the purposes of financial policy of the } \\
\text { enterprise; decrease in part of borrowed funds in economic circulation, etc. }\end{array}$ \\
\hline & & Diversification & $\begin{array}{l}\text { Process of distribution of the capital between different objects of an investment } \\
\text { which are directly not connected among themselves. Diversifications are subject } \\
\text { different types of activity, suppliers of goods, the product ranges, a deposit } \\
\text { portfolio and a portfolio of securities. }\end{array}$ \\
\hline & & Limitation & $\begin{array}{l}\text { Establishment of a limit (extreme sums) of expenses, volumes of realization, } \\
\text { credit, etc. }\end{array}$ \\
\hline \multirow[t]{3}{*}{4} & \multirow{3}{*}{$\begin{array}{l}\text { Evasion from } \\
\text { risk }\end{array}$} & $\begin{array}{l}\text { Refusal of unreliable partners, } \\
\text { innovative projects, some types } \\
\text { of economic activity }\end{array}$ & \\
\hline & & Insurance & \\
\hline & & Search of « guarantors» & \\
\hline \multirow{3}{*}{5} & \multirow{3}{*}{$\begin{array}{l}\text { Localization of } \\
\text { risk }\end{array}$} & $\begin{array}{l}\text { Allocation of «economically } \\
\text { dangerous sites in structural } \\
\text { or financially independent } \\
\text { divisions }\end{array}$ & $\begin{array}{l}\text { These methods are based on identification of such sites of activity of the } \\
\text { enterprise where there is rather high concentration of factors of economic risk, } \\
\text { for the purpose of their isolation in independent registration - financial or } \\
\text { organizational and legal structure }\end{array}$ \\
\hline & & $\begin{array}{l}\text { Formation of the venture } \\
\text { enterprises }\end{array}$ & \\
\hline & & $\begin{array}{l}\text { Consecutive disaggregation of } \\
\text { activity }\end{array}$ & \\
\hline \multirow{3}{*}{6} & \multirow{3}{*}{$\begin{array}{l}\text { Dissipation of } \\
\text { risk }\end{array}$} & $\begin{array}{l}\text { Diversification of kinds of } \\
\text { activity, sales markets and } \\
\text { zones of managing, investment } \\
\text { portfolio of the enterprise, etc. }\end{array}$ & $\begin{array}{l}\text { These methods consist in distribution of the revealed risk factors between } \\
\text { participants of production and by that in an exception of excessive } \\
\text { concentration of risk at any one producer. }\end{array}$ \\
\hline & & \begin{tabular}{|l|} 
Integration distribution of \\
responsibility between partners \\
in production
\end{tabular} & \\
\hline & & \begin{tabular}{|l|}
$\begin{array}{l}\text { Distribution of risk behind work } \\
\text { stages (behind time) }\end{array}$ \\
\end{tabular} & \\
\hline \multirow{6}{*}{7} & \multirow{6}{*}{$\begin{array}{l}\text { Compensation } \\
\text { of risk }\end{array}$} & $\begin{array}{l}\text { Creation of reserve funds at the } \\
\text { enterprise }\end{array}$ & $\begin{array}{l}\text { These methods are based on formation of the mechanism of the warning } \\
\text { action which provide development and realization of preventive analytical, } \\
\text { organizational and other actions on decrease in level of economic risk }\end{array}$ \\
\hline & & $\begin{array}{l}\text { Introduction of strategic } \\
\text { planning at the enterprise }\end{array}$ & \\
\hline & & $\begin{array}{l}\text { Forecasting of an external } \\
\text { economic situation in the } \\
\text { country, the region and } \backslash \text { or area } \\
\text { of managing }\end{array}$ & \\
\hline & & \begin{tabular}{|l|} 
Active purposeful \\
(《aggressive») marketing at the \\
enterprise
\end{tabular} & \\
\hline & & \begin{tabular}{|l|} 
Lobbying of bills which \\
neutralize or is compensated by \\
risk factors
\end{tabular} & \\
\hline & & $\begin{array}{l}\text { Fight against industrial and } \\
\text { economic espionage }\end{array}$ & \\
\hline
\end{tabular}


enterprise of their major factors and elimination of negative influence of these factors on results of economic activity on the basis of adoption of the relevant administrative decision.

Except that the approach stated above gives an opportunity to connect major factors of risks with the most widespread business - processes of economic activity of the enterprises of agro-industrial complex, it will also give the chance to the enterprises most thoroughly to build process of management of risks at a stage of making decision on such questions: whether it is expedient to accept this risk, to operate it, to transfer to the third parties (for example, to insurance companies) or to refuse it?

\section{Methods of management of risks}

The choice of methods of management of economic risks at the enterprises of agrarian sector of economy is one of key stages of process of management of risks. In the general understanding, risk management in economy represents set of the processes connected with identification, risk analysis and decision-making which provide maximizing positive and minimization of negative consequences of approach of risky events (Urodovskikh, 2010).

Methods of management of economic risks include receptions and ways of actions which are directed to achievement of a main objective on management of economic risk.

Main objective of management of risk in agro-industrial complex is elimination or minimization of its negative influence on results of economic activity of the enterprise, on the basis of forecasting of a risky event and realization of actions for management of risk.

The choice of methods of management of economic risks in agro-industrial complex is carried out taking into account seasonality of agricultural production, influence of the risk caused by action of weather conditions, and rather slow turnover of the capital in comparison with other branches of economy.

On the basis of research of sources of scientific literature by the author the generalized classification of methods of management of economic risks at the enterprises of agroindustrial complex (tab. 3) is developed.

Apparently from table 3 some methods of management of risks belong to the different classification directions. For example, such most widespread method of management of risk as insurance is classified as: a way of influence on risk, decrease in risk, evasion from risk. The method of diversification of risks is carried to the direction of prevention of risks and to the direction of dissipation of risks. Authors classify creation of reserve funds (means, goods, stocks, etc.) as reception of decrease and as reception of compensation of risk. At the same time approaches to structurization of methods of management of risks vary according to research objectives.

Thus, the category of economic risk has the difficult multidimensional nature therefore the tools of management of risk are considered from different positions according to the chosen context of interpretation of essence of economic risk.

In our opinion, all variety of methods of management of risks from positions of distribution or transfer of risks can be marked out in two main directions which are specified in tab. 4.

\section{Table 4}

\section{Classification of the main methods of management of economic risks at the enterprises of agrarian and industrial complex}

\begin{tabular}{|l|l|}
\hline \multicolumn{2}{|c|}{ Methods of management of economic risks } \\
\hline $\begin{array}{l}\text { Methods of minimization of } \\
\text { risks at the expense of own } \\
\text { resources of the enterprise }\end{array}$ & $\begin{array}{l}\text { Methods of division and } \backslash \text { or } \\
\text { transfer of risks to the third } \\
\text { parties }\end{array}$ \\
\hline $\begin{array}{l}\text { Refusal of unreliable partners, } \\
\text { innovative projects, some types } \\
\text { of economic activity }\end{array}$ & Hedging \\
\hline Creation of reserve funds & External insurance \\
\hline Self-insurance & Diversification \\
\hline Limitation & \\
\hline Business Planning & \\
\hline $\begin{array}{l}\text { Obtaining additional } \\
\text { information }\end{array}$ & \\
\hline
\end{tabular}

Methods of minimization of risks at the expense of own resources of the enterprise belong to the first direction.

Refusal of unreliable partners, investment projects which efficiency of introduction has doubtful character is quite widespread method of avoidance (prevention) of economic risk. As a rule, such tactics observe those subjects of managing which have got used to work for certain, without risking. Such tactics renders assistance to continuous development of the agro-industrial enterprise, nevertheless, when its intensive development given a method of management of risk becomes a main objective of the enterprise isn't effective.

Effective method of management of economic risks is creations of reserve fund of money by assignment of percent from net profit on a case of emergence of unforeseen situations. For the purpose of management of economic risk in agrarian sector are subject to reservation not only money, but also stocks of raw materials, materials and accessories and etc. At the same time it is expedient to create as intraeconomic reserve funds (reserve funds of money, compound feeds, fuel, etc.), and centralized (the state reserve reserves of grain, seeds, etc.).

Method of prevention (minimization) of influence of economic risks of the enterprises of agrarian sector of economy is business planning which sets heads of the enterprises thinking of problem sites («bottlenecks») in economic activity and to find ways of elimination of negative manifestations of risk factors or their neutralization. As the accompanying method of management of economic risk when planning economic activity obtaining additional information of rather future events or contractors of 
economic activity for the purpose of elimination of uncertainty concerning emergence of adverse situations which appear as a result of influence of factors of external and internal environment of the sphere of managing can act.

Having additional information of rather future events and risk factors, the management of the enterprise can make the relevant decisions concerning neutralization or full elimination of risk factors according to the level of their danger to economic activity of the enterprise.

Limitation as a method of management of economic risks consists in establishment of limits (the extreme sums) of expenses of means, purchases or sales of stock, capture of obligations of the credit and etc. This method is effective in a situation when the enterprise has limited resources.

Effective method of management of economic risk is self-insurance. It is expedient to apply this method in a case when the cost of property which is insured, is small in comparison with financial losses of all business or when there is a probability of damage. As a rule, self-insurance is carried out by the enterprise at the expense of means of reserve fund and renders assistance to economy of enterprise assets due to refusal of payment of insurance premiums to other person - insurance company.

Methods of division and/or transfer of risks to the third parties belong to the second group of management of economic risks.

The most widespread and effective method of management of economic risk in agrarian sector is agricultural insurance. It is a complex type of insurance which includes insurance of crops, animal, capital assets of agricultural producers.

The leading role in agricultural insurance in Ukraine is assigned to the state which at the legislative level provides insurance of risks of agricultural producers and carries out thereby a number of the major functions (Zakharchenko \& Osipov, 2010):

- risky function which essence consists in redistribution of a monetary form of cost among participants of insurance of consequences of casual insurance events. According to art. 11 of the Law on the state support of agriculture of Ukraine by the public specialized institution which is created for granting insurance subsidies to producers of agricultural production, it is the Fund of agrarian insurance subsidies of Ukraine (FAIS). The income of FAIS is formed for the account: obligatory assignments by insurers from the sum of the insurance premiums got owing to obligatory or voluntary insurance of separate types of agricultural production; primary contribution from the state budget; credits of the state budget;

- precautionary function which is directed to financing at the expense of part of means of insurance fund of actions for reduction of insurance risk;

- investment function consists in attraction of investments into real sector of economy.

Effective method of decrease in price and inflationary risks for the enterprises of the agrarian sphere of economy is hedging which is carried out by drawing up such forms of exchange contracts as futures and options.

The future is a contract for delivery (purchase) to the term of a certain quantity of goods determined in the future at the price existing nowadays (Vasin \& Shutov, 2010).

The option is an agreement under which the buyer acquires the right for purchase (sale) of goods at in advance agreed price.

It should be noted that the main difference between an option and the future is that delivery according to the future is obligatory whereas on an option it has probable character. In other words, signing the contract an option, the enterprise can refuse him, having lost only a sum of guarantee providing (award).

So, for example, the agricultural producer, having signed the contract concerning sale of a certain quantity of the harvest (which at the time of signing of the contract hasn't ripened yet) at determined price, insures itself against adverse fluctuation in prices of his production. To the contrary, for the purpose of decrease in risk from increase in prices for resources (fuel, fertilizers, forages, equipment, spare parts, seeds, etc.) the same agricultural producer can sign urgent agreements on purchase of these resources through some period of time at the price existing nowadays. Thus, the agricultural producer is hedged.

At hedging operations the agricultural producer reports the risk to other person - the exchange speculator.

In Ukraine the state acts as such main exchange speculator, buying risk from agricultural producers and not allowing sharp fluctuation in prices of agricultural products. Such activity of the state leads to shift of consumption in time: buying agricultural products in fruitful years, the state sells them in years of a crop failure (Zakharchenko \& Osipov, 2010).

So, for the purpose of the solution of a situation of uncertainty and minimization of economic risks the Law on grain and the market of grain which main objective according to Art. 2 is ensuring food security of the state with way acts on the market of grain in Ukraine: formations of investment, credit, tax, customs policy, favorable for market of grain; optimization of structure and efficiency of grain production taking into account the potential of climatic conditions and market conditions; ensuring functioning of the market of grain on the basis of association of free competition and state regulation for the purpose of balancing of interests of subjects of managing and the state; establishment of the state control of quality of grain, products of its processing and high-quality seeds; stabilization of market resources of grain; building of an export potential of the market of grain; recognition of priority of development of the market of grain; application of the mode state purchases; implementation of the state agrarian intervention; definition of an order of export and import of grain and products of its processing according to international treaties (The law of Ukraine «About grain and the market of grain in Ukraine», 2002). 
Regulation of fluctuation in prices of agricultural products is regulated by the Law of Ukraine «About the state support of agriculture of Ukraine $\gg$ from 06/24/2004 No. 1877-IV. In article 3 of this Law the rules of price regulation on separate types of agricultural products are defined, namely: the state represented by Agrarian fund of the state interventions carries out regulation of the group prices of separate types of agricultural production, establishing the minimum and maximum intervention prices within the agrarian market of Ukraine.

In our opinion, the most perspective method of management of economic risk in the agrarian sphere of economy is the diversification method. Diversification is the most reasonable and rather less expensive way of decrease in risk which allows spreading the general risk by association with other participants who are interested in success of common cause. I.e. the enterprise has an opportunity to reduce the level of own risk, attracting to the solution of common problems as partners other enterprises.

The method of diversification of economic risks in the sphere of agro-industrial complex can be applied in case of creation of regional clusters by association of resources of participants of a cluster and distribution of risks between them.

The regional cluster is a spatial agglomeration of similar and economically connected kinds of activity which forms a basis of the local environment due to dissemination of knowledge and skills, and also renders assistance and stimulates different forms of education and adaptations. Such clusters, as usual, consist of small and medium-sized enterprises which basis of success is made by the saved-up capital and geographical proximity (Zakharchenko \& Osipov, 2010).

When forming regional agro-industrial clusters in Ukraine it is worth to remember about a role of the state in this process which has to emphasize in every possible way importance of creation of the most perspective business projects, attracting investments to their development and to be ready to share risks at all stages of implementation of this project.

Considering the aforesaid, it is possible to draw the following conclusions:

- among methods of minimization of risks at the expense of own resources of the enterprises of the agrarian sphere of economy an effective method of management is the limitation method;

- among methods of division and \or transfer of risks to the third parties of special attention insurance in agriculture, the leading role in which is assigned to the state, deserves;

- a perspective method of management of risks in the sphere of agro-industrial complex is the method of diversification of risks which effective form of implementation there is a creation of territorial clusters.

It should be noted that use of levers of state regulation of risks of agro-industrial complex has to be the integral component of a rational risk management of the agroindustrial enterprise.

\section{Conclusions}

Thus, by results of the conducted research the economic content of risk by definition of its basic elements has been specified, the concept of economic risk and the scheme of distribution of risk factors of economic activity of the enterprises of agro-industrial complex depending on main types of business processes and possible degree of their controllability is offered. Besides, the economic essence of process of management of economic risks at the enterprises of agro-industrial complex, feature of classification of methods of management of economic risks has been defined.

Streamlining of subject domain of risk management of economic activity and the offered structurization of risk factors create prerequisites for increase of system effectiveness of management at the enterprise due to reduction of negative influence of risk factors, increase of level of validity of administrative decisions in short-term and long-term the periods.

The direction of classification of methods of management of risks from positions of their distribution or transfer is offered by the author, and also practical aspects of the choice of methods of management of economic risks at the enterprises of agrarian sector of economy are considered.

On the basis of the conducted research it is proved that a perspective form of diversification of risks in the sphere of agro-industrial complex is creation of regional clusters.

\section{References}

Alshanova, O.O. (2010). Insurance in risk management of cultivation of crops. Economy of agrarian and industrial complex, 10, 86-91.

Balabanov I.T. (1996). Risk management. Moscow: Finance and statistics, 191 p.

Chepurko, V.V. (2000). Economic risk of agrarian production: автореф. yew. ... doctors of icons. sciences: 08.07.02. Kiev: NAN of Ukraine. Institute of economy, 33 p.

Donets, L.I., Shepelenko, O.V., Barantsev S.M., Sergeyev O.V. \& Veremeychik O.F. (2012). Justification of economic decisions and estimation of risks. Kiev: Center of educational literature, $472 \mathrm{p}$.

Illyashenko, S.M. (2004). Economic risk: Manual. Kiev: Center of educational literature, 220 p.

Kachalov, R.M. (2002). Management of economic risk. Moscow: Science, 192 p.

Khokhlov, N.V.(2001). Management of risk: Studies. A grant for higher education institutions. Moscow: UNITY-DANNA, 239 p. 
Krylatykh, E.N. (2010). Agrofood sector: multifunctionality, development factors, risks. Economy of agrarian and industrial complex, 2: 162-165.

Skripnik, A.V. \& Shevchuk, Yu.V. (2011). Methodology of an assessment of risks of the agrarian enterprise. Economy of agrarian and industrial complex, 10: 101-108.

The law of Ukraine «About grain and the market of grain in Ukraine» (2002). Sheets of the Verkhovna Rada of Ukraine., 35, St. 258. Retrieved from: http://zakon5.rada.gov.ua/laws/show/ 37-15

The law of Ukraine «About the state support of agriculture of Ukraine» (2004). Sheets of the Verkhovna Rada of Ukraine, 49, St. 527. Retrieved from: http://zakon4.rada.gov.ua/laws/show/ 1877-15

Urodovskikh, V.N. (2010). Risk management of the enterprise: Manual. Moscow: High school textbook: INFRA-M, $168 \mathrm{p}$.

Vasin, S.M. \& Shutov, V.S. (2010). Risk management at the enterprise: manual. Moscow: KNORUS, 304 p.

Zakharchenko, V.I. \& Osipov, V.N. (2010). The Cluster form of the territorial and production organization P. 1. - Economic clusters as a new form of the organization of production in the region. Odessa: «Favourite» «The printing house», $122 \mathrm{p}$.

Zbarsky, V.K. \& Lipovyak-Melkozyorova A.I. (2011). Nature of risk, his sources, criteria and assessment. Economy of agrarian and industrial complex, 8: 61-65.

\section{Лилия МАРТЫНОВА}

\section{РИСК: ЭКОНОМИЧЕСКОЕ СОДЕРЖАНИЕ, ФАКТОРЫ И МЕТОДЫ УПРАВЛЕНИЯ}

Аннотация. Целью статьи является определение экономического содержания рисков, их классификации и методов управления, исследование влияния основных факторов риска на результаты хозяйственной деятельности предприятий агропромышленного комплекса по возможной степени ихуправляемости, а также обоснование выбора наиболее оптимальныхметодов управления хозяйственными рисками на предприятиях аграрного сектора экономики. Методология. Данные для исследования были взяты из научных публикаций и законодательной базы. Использованы методы общенаучного познания, а также структурного анализа и контент-анализа. Результаты. На основе обобщения подходов к определению категории «экономического риска» автором предложено собственное определение этой категории, предложена схема распределения факторов риска хозяйственной деятельности предприятий агропромышленного комплекса в зависимости от основных видов бизнес-процессов по возможной степени их управляемости, а также автором предложено направление классификации методов управления рисками с позиций их распределения или передачи, кроме того рассмотрены практические аспекты выбора методов управления хозяйственными рисками на предприятиях аграрного сектора экономики. Практическое значение. Упорядочение предметной области управления рисками хозяйственной деятельности и предложенная структуризация факторов риска создают предпосылки для повышения эффективности системы управления на предприятии за счет уменьшения отрицательного влияния факторов риска, повышения уровня обоснованности управленческих решений в краткосрочном и долгосрочном периодах. Значение/оригинальность. На основе проведенного исследования обосновано, что перспективной формой диверсификации рисков в сфере агропромышленного комплекса является создание региональных кластеров. 